\title{
AN “ARMY OF AMAZONS": THE LANGUAGE OF PROTEST IN A KANSAS MINING COMMUNITY, 1921-22
}

\author{
ANN SCHOFIELD \\ The University of Kansas $D$
}

ON SUNDAY, DECEMBER 11, 1921, FIVE HUNDRED WOMEN FROM THE VARIOUS mining camps of the Kansas "Little Balkans" crowded into a church hall in Franklin. Caught in a protracted strike and faced with dwindling family incomes, they resolved to take action. By the next day their ranks had swelled to several thousand women who, marching behind a billowing American flag and singing patriotic songs, blocked the entrances to mines, threw pepper in workers' eyes and may even have beaten several miners in an attempt to stop strikebreakers from jeopardizing the four-month-old miners' walkout.

Pittsburg, the largest city of Crawford County, braced for an assault by the "'army of Amazons." The sheriff frantically assembled a deputized force of one thousand men and recruited veterans who stockpiled rifles and guns in a local hotel. Excitement in the town heightened as three troops of Kansas National Guard cavalry arrived on December 15 to take up positions in the Ringo, Mulberry and Franklin coal camps.

But the "army" never attacked. Restrained by the authorities, the women were subjected to harsh legal reprisals following their march. Forty-nine women were charged with unlawful assembly, assault and disturbing the peace; bond was set at seven-hundred-fifty dollars rather than the customary two hundred dollars. When tried in January the women pleaded guilty and were fined anywhere from one dollar to two hundred dollars, paroled and ordered to pay court costs.

At first glance the women's march seems the stuff that enlivens local history. Its drama pulls us toward the community concerns that inspired its participants-labor solidarity and family wages. But deeper analysis of that drama, most especially of the rhetoric of protest employed by the women, leads to even more substantive questions. The "language" of the march, both nonverbal and spoken, reflected important social tensions of the time: the struggle between modern and traditional values, between the dominant society 
and an ethnic population, between labor and capital. It depicts as well women's participation in the unique culture of a mining community.

That culture-the values, institutions and shared experience focusing on the mines-connected the public world of work and the private world of domesticity for women in a way that was a specifically working-class experience. Through the march, women expressed their collective stake in the community as wives and mothers in family units whose economic viability was threatened by the public event of the strike. In symbol and rhetoric, the women laid claim to their rights as Americans and defined their concept of femininity. The women's behavior and its description by contemporary observers also reflects the range of political and social conflict that existed in southeastern Kansas and, paradoxically, a consensus as to what constituted appropriate moral behavior. Critics felt the march challenged fundamental values associated with flag and family while participants viewed their actions as a defense of those very same values. Patriotism and domesticity seemed cherished beliefs for each side; conflict consisted in the substantive or behavioral content of those categories. Before turning to the women's march, however, it is important to understand the issues of the strike, the nature of southeastern Kansas mining communities, and the economic context in which the march took place.

The women's march formed but one chapter of a turbulent era in American labor history. In the years following the First World War, John L. Lewis struggled to achieve and then to maintain leadership of the United Mine Workers of America (UMWA). Alex Howat, the "rambunctious, argumentative, and tempestuous" president of Kansas District 14 repeatedly challenged Lewis; indeed, he led Kansas miners out on strike in September 1921 in defiance of Lewis's orders. That strike, ostensibly over a change in work rules at the Dean and Reliance mine near Pittsburg, Kansas, was complicated by a number of other issues, the foremost of which was Howat's ambition. Idolized in the Kansas coal communities for his consistent pose as a "militant class warrior," Howat demonstrated, nonetheless, a poor understanding of the political situations both in Kansas and in the international union. The Kansas legislature, partially in response to the chaotic situation caused by repeated miners' walkouts, had passed a compulsory arbitration law in 1920 known as the Industrial Court. Although Lewis was opposed to the law in principal, in the interest of stabilizing the Kansas situation he enjoined Howat to honor a contract which the UMWA had signed with the South Western Coal Operators Association, whose terms forbade strikes until issues were adjudicated by a joint union management committee. When Howat defied both the union demand to honor the contract and the state demand for compulsory arbitration, the union voted to suspend him; the state put him in jail. As Melvyn Dubofsky and Warren Van Tine have written: "Howat ... proved unable to distinguish between strikes for a good cause and those without reason, between walkouts banned by a 
law that the UMW challenged in court and those that the UMW pledged to enforce." 1

While this may be a fair historical assessment of the mercurial Alex Howat, the fact remains that Howat was a folk hero in the Kansas coal fields and his imprisonment was taken as a symbol of the injustice felt by the rank and file miners. ${ }^{2}$ Failing to recognize Howat's local importance, Lewis installed Van Bittner as provisional head of District 14 in the fall of 1921. Bittner then used the international union payroll to hire Lewis supporters and he convinced surrounding districts (Oklahoma-Arkansas-Texas, Iowa, Missouri) not to accept transfer cards from Kansas miners. Both actions seriously undermined the strike; by late November the mines were operating at about half their capacity as increasing numbers of miners returned to work. These actions had critical economic repercussions for miner's households because here, as in mining communities elsewhere, the mines were the single source of employment.

Kansas miners and their families knew all too well the impact of strikes on household budgets particularly during a time of steadily declining incomes. Coal was one of America's "sick" industries during the 1920s as reflected in the persistent irregularity of miner's wages. Walter Hamilton and Helen Wright pointed out the implications of wage fluctuations for the family: " $\ldots$. . if a miner worked the number of days that the industry formerly averaged and earned the average wage at the present union scale, he would earn between $\$ 1800$ and $\$ 2000$ in a year. Even this wage would not provide the estimate of Bureau of Labor Statistics for minimum requirements of "health and decency.", 3 They correctly concluded that "such incomes would give the housewife an impossible task," for the welfare of the household was totally contingent upon the miner's wage, thus giving wives as household managers a particularly immediate connection to workplace issues.

'Melvyn Dubofsky and Warren Van Tine, John L. Lewis: A Biography (New York: Quadrangle, 1979), 115. See also Joseph Skubitz, Jr., "A History of the Development of Deep Mine Production in Crawford County and the Factors that Have Influenced It," M.S. Thesis, Kansas State Teachers College (Pittsburg State University), 1934; Domenico Gagliardo, The Kansas Industrial Court (Lawrence: Univ. of Kansas Publications, 1931); Irving Bernstein, The Lean Years: A History of the American Worker, 1920-1933 (Baltimore: Penguin Books, 1966).

${ }^{2}$ Mary Heaten Vorse described Howat as an idol to Kansas miners under whose leadership " people stopped being afraid." Mary Heaton Vorse, "Ma and Mr. Davis," Survey, 49 (15 Dec. 1922), 359-60. The 1921 strike, however, became so identified with the local leader that it was known as the "Howat strike," Gagliardo, Kansas Industrial Court, and one contemporary supporter of the Industrial Court found the "obdurate" Howat was the principal cause of the vicious 1919 strike. See also John Hugh Bowers, The Kansas Court of Industrial Relations: The Philosophy of the Court (Chicago: A. C. McClurg \& Co., 1922), 28.

${ }^{3}$ Walter Hamilton and Helen Wright, The Case of Bituminous Coal (New York: Macmillan Co., 1928), 78-80. See also Van Bittner, "Wages in Bituminous Coal Mines as Viewed by the Miners", and Anne Bezanson, "Earnings of Coal Miners"' in Clyde L. King, ed., The Price of Coal: Anthracite and Bituminous in The Annals the American Academy of Political and Social Science, 111 (Jan. 1924). 
In many other ways the communities surrounding Pittsburg resembled typical mining communities. ${ }^{4}$ Towns with populations ranging from 100 to 1000 made up the coal mining area of southeastern Kansas. Centered primarily in Crawford and Cherokee Counties, the mine field consisted of twenty or so small mining camps located anywhere from two to fifteen miles from the city of Pittsburg. ${ }^{5}$ Life was dictated by the rhythms of the mine; sudden death, economic insecurity and a traditional work culture were the norm. ${ }^{6}$ For men this work culture consisted of obvious elements: the dangers of the occupation, the underground work environment, the power to effect an immediate work stoppage, a body of myths, songs and superstitions and the focal institution of the union, the United Mine Workers of America. It included also a sporadic pattern of employment and unemployment-miners were idle at least one-third of the year. ${ }^{7}$ When asked how miners amused themselves when out of work, one miner testified to the economic and psychic instability of the miner's family with his taciturn reply: "What do we do when we are out of work? . . Why we sit around or start a fight. There is nothing else to do." 8 Few mining towns provided any outlet for this enforced leisure-evening schools, reading rooms and free libraries were in short supply. For women the towns offered little external to the family or mines that was "stimulating or developing." 9 Unlike the middle-class women of Pittsburg whose activities in such clubs as the Helpers, the Queen Esthers and

\footnotetext{
${ }^{4}$ There is neither an institutional history of the United Mine Workers of America nor a comprehensive social history of mining on the United States. The best guide to the various articles and monographs on mining and life in communities is Robert F. Munn, The Coal Industry in America: A Bibliography and Guide to Studies (Morgantown: West Virginia Univ. Library, 1965). Two studies of mining communities in Great Britain which are suggestive for the analysis of American communities are John Benson, British Coal Mining in the Nineteenth Century: A Social History (New York: Holmes and Meier Publishers, Inc., 1980) and Michael Hanies, "Fertility, Nuptiality, and Occupation: A Study of Coal Mining Populations and Regions in England and Wales in the Mid-Nineteenth Century," Journal of Interdisciplinary History, 8 (Autumn 1977), 245-80. See also David A. Corbin, Life, Work and Rebellion in the Coal Fields: The Southern West Virginia Miners, 1880-1922 (Urbana; Univ. of Illinois Press, 1981), and Alan J. Linger, "'What Side Are You On?': Ideological Conflict in the United Mine Workers in America, 1919-1928," Diss. Rutgers Univ. 1982.

${ }^{5}$ Strip coal mining began in Crawford Co., Kansas in 1850 and the first shaft mine was sunk in 1874. By 1898 there were 53 deep pit mines operating in Crawford Co., the leading coal producing area of the state. Production of coal increased in Crawford Co. from 221,741 tons in 1885 to $4,508,747$ tons in 1920 , the year in which production began to decline. The market for Kansas coal included both domestic and railroad use and was dominated by seven to ten large companies. Vorse, "Ma and Mr. Davis."

${ }^{6}$ There were 19 fatal and 836 nonfatal mine accidents in Kansas in 1920. State of Kansas 35th Annual Report of Department of Labor and Industry, Topeka, 1920.

${ }^{7}$ Annual Report of Coal Mine Inspector and Mine Rescue Departments, State of Kansas, 1921. Mine production slowed during the summer when most miners worked 2-3 days of the week.

${ }^{8}$ May Wood-Simons, "Mining Coal and Maiming Men," The Coming Nation, 6 (11 Nov. 1911), 4. See also Marie L. Obenauer, "Living Conditions Among Coal Mine Workers if the U.S." in King, The Price of Coal, 12-23.

${ }^{9}$ Hamilton and Wright, The Case of Bituminous Coal, 82-84.
} 
the Worthwhile filled the pages of local newspapers, miner's wives centered their lives on the camps.

Working-class women shared more with the men of the community than this lack of a cultural outlet, for their distinct roles were shaped by the presence of the mines. The stark figure of the woman at the mine entrance conveyed the immediacy of numerous mine accidents for miners' families, accentuated in an age with few survivor's benefits and inadequate state workmen's compensation acts. ${ }^{10}$ A daily ritual was the hot bath which miners' wives were responsible for having ready for the filth-encrusted miners when they returned from the mines. Furthermore, the union sponsored some of the few social events held in the mining camps such as the Dante Allegheri Clubs for wives of Italian miners. Wives shopped in company stores and lived in company houses.

Like the women described by historians Susan J. Kleinberg ${ }^{11}$ and Glenna Matthews ${ }^{12}$ in other one-company towns, these women were rarely employed outside of the home; the demands of domestic work without modern appliances, in addition to the narrow occupational structure and physical isolation of the camps, precluded wage work for women. Unlike more heterogeneous industrial communities where wives contributed to family income by taking in boarders or doing seasonal work, census data for Pittsburg and its environs indicated an overwhelming majority of nuclear family households, few boarders and a miniscule number of wage-working wives. ${ }^{13}$ Women shared the burden of economic insecurity by forming "networks" through trading bread, eggs and garden produce and through midwives' visits from house to house. When asked if she had worked outside the home to help make ends meet one miner's wife replied, "Of course not, no one did-who would take care of the children?" $14 \mathrm{It}$ seems clear that even though there was a strict sexual division of labor in mining towns, the mines themselves were central to the community and had a profound impact on both men and women. Once again, the role of the mines in the Kansas

\footnotetext{
10Ibid.

"Susan J. Kleinberg, "Technology and Women's Work: The Lives of Working Class Women in Pittsburg, 1870-1900," Labor History, 17 (Winter 1976), 59-72.

${ }^{12}$ Glenna Matthews, "An Immigrant Community in Indian Territory," Labor History, 23 (Summer 1982), 374-94.

${ }^{13}$ Census, Kansas State 1925, manuscripts for Pittsburg. See also United States Immigration Commission (Dillingham Commission) Immigrants in Industries, United States Senate Documents, 61st Congress, 2nd Session, No. 633, Vol. II, Part I (Hereafter Dillingham Commission). The analysis of Franklin, a representative mining community with a total population of 1409 showed 87.7 percent of the population living in nuclear family households, 6.9 percent in multigenerational households and 5.4 percent in households classified as "other" (indicating the presence of boarders). The homogeneity of the population is indicated by the fact that 25.1 percent were miners, 20.4 percent housewives and 43.0 percent students and children. The Dillingham Commission claims that of 542 households surveyed in the Kansas coal districts 82.5 percent of native born and 98.4 percent of foreign born women were at home.

${ }^{14}$ Interviews with Mrs. Anna Okorn and Mrs. Clemencia DeGrusin, Pittsburg, Ks., 29 Aug. 1981.
} 
coal fields should remind us of the very permeable boundaries that existed between public and private life for working-class people. ${ }^{15}$

In many ways, this interaction between home life and work life characterized mining communities everywhere. June Nash, for example, found in her study of Bolivian tin miners that miners' wives publicly shamed husbands following a domestic quarrel by refusing to bring their lunch buckets to the mine. And wives of miners, organized by community, marched to defend their interests in Maryland in 1894, on the Mesabi Iron Range in 1916 and in Colorado in 1927, to name but a few instances. ${ }^{16}$ In some instances, even death, that most individual of experiences, drew the community into a work-related ritual. In 1917, for example, the body of a young Italian miner killed by a gas explosion was taken to Pittsburg where it was met by a band and carried behind an empty hearse to its grave accompanied by several hundred fellow miners. ${ }^{17}$ Briefly, then, we can see that the women and men of mining towns shared values and traditions which centered on the mine to a point where we can genuinely expand the definition of work culture beyond the workplace to encompass the entire community.

Ethnicity, however, also colored the culture of the Kansas Balkans. As Kansas coal mines expanded between 1877 and 1879, Welsh coal miners migrated from the coal fields of Pennsylvania to Kansas. Following that date, until 1898, the need for workers was so great that coal companies sent agents to Illinois and Pennsylvania coal fields as well as to the port of New York to recruit miners. Agents met immigrants at the pier and, if they had been miners in Europe, promised them transportation to the Kansas coal fields. Miners also came to Kansas from Indian Territory (now Oklahoma) during labor disputes in that area between the years 1882 and 1895 . Once immigrants established themselves in Kansas, they soon sent for family, friends and countrymen to join them. By the turn of the century, southeastern Kansas was a polyglot area peopled by Italians, Germans, French, Belgians and a variety of ethnic groups from the British Isles and the Austro-Hungarian Empire. ${ }^{18}$ The contrast which the ethnic population of

\footnotetext{
1sSee Elizabeth Pleck, “Two Worlds in One: Work and Family," Journal of Social History, 10 (Winter 1976), 178-95, for an early formulation of the permeability of private/public spheres in working class history.

${ }^{16} \mathrm{June}$ Nash, We Eat the Mines and the Mines Eat Us: Dependency and Exploitation in Bolivian Tin Mines (New York: Columbia Univ. Press, 1979). Katherine A. Harvey, The Best-Dressed Miners: Life and Labor in the Maryland Coal Region (Ithaca: Cornell Univ. Press, 1969), 283ff. Charles J. Bayard, "The 1927-1928 Colorado Coal Strike," Pacific Historical Review, 32 (1963), 235-50; Industrial Worker, (5 Aug. 1916), 1.

${ }^{17}$ The Arma Record, 4 Jan. 1917, 3.

${ }^{18}$ Fred N. Howell, "Some Phases of the Industrial History of Pittsburg, Ks.," Kansas Historical Quarterly, 18 (1952), 273; William E. Powell, "The Historical Geography of the Impact of Coal Mining Upon the Cherokee-Crawford Coal Field Of Southeastern Kansas," Diss. Univ. of Nebraska 1970, and idem, "Former Mining Communities of the Cherokee-Crawford Coal Field to Southeastern Kansas,” Kansas Historical Quarterly, 38 (1972), 187-99.
} 
the mining camps struck with the surrounding environment caused one observer to note in 1911, "at no place west of the Mississippi is there a similar large group of industrial immigrants living in the very midst of a flourishing rural community." 19

Still, work, rather than ethnicity, ultimately determined community in southeastern Kansas. With the exception of the Italians, immigrants did not cluster together into residential enclaves as they did in eastern urban areas and they formed fewer distinctively ethnic organizations. ${ }^{20}$ The Catholic church, for example, never sent priests to minister to one particular ethnic group and encouraged the foreign-born to Americanize as quickly as possible. One study of a local baptismal registry found: ". . . most nationalities married outside of their own nationalities including frequent intermarriage between American and foreign-born." ${ }^{21}$ While cross-ethnic, these marriages were rarely cross-classthe "Americans" were usually the children of immigrants or miners themselves.

Thus, the coal companies and the mine itself dominated life in the mining camps. Coal companies built these camps-Franklin, Arma, Mulberry, Camp 50, Chicopee and a host of others-to house workers as close as possible to shaft mines. As one geographer explained this pattern of settlement: "There is thus created near the openings of the mines a sort of artificial city, with houses exactly alike which are the 'result' and the necessary 'sign' of the work underground.", 22 Many of these houses, or more appropriately shacks, were owned by the mining companies as were the company stores where miners and their wives bought groceries in exchange for script. ${ }^{23}$ Some camps boasted churches, schools and dance halls while others were simply dreary rows of three-room shacks. There was a higher incidence of smallpox, measles, scarlet fever, typhoid, malarial fever, pneumonia and other respiratory illnesses in the camps than in the surrounding area. Nutritional standards were also lower; stews and soups rather than meat provided the main protein source for family's diets. In a poignant testament to this fact, a Dunkirk schoolchild once began an essay on cows with the sentence, "The meat of a cow is called soupbone." 24

Families dealt with this insecurity in a number of different ways. They frequently planted large vegetable gardens and preserved or canned the produce which they stored in cellars behind their shacks; those without cellars stored vegetables under the house and piled straw or dirt over them. Italians were especially noted for growing herbs, fig trees and grapes for wine. ${ }^{25}$ Mining

\footnotetext{
${ }^{19}$ Wood-Simons, "Mining Coal and Maiming Men."

${ }^{20}$ Dillingham Commission.

${ }^{21}$ Kenneth Melaragno, "Immigrants as Viewed through the Baptismal Register" (unpub. ms., Pittsburg, Ks., 25 Aug. 1981), studies the Registrum Baptizatorum in Ecclesia Santa Mariae de Lourdes for 1855-1928. 1 am indebted to Eugene DeGruson for bringing this paper to my attention.

22Jean Brumbes, Human Geography (Chicago: Rand McNally Co., 1920), 386.

${ }^{23}$ Wood-Simons, "Mining Coal and Maiming Men," describes Kansas miners" homes.

${ }^{24}$ Ibid. See also Dillingham Commission.

${ }^{25}$ Powell, "Historical Geography, " 299.
} 
families also kept hogs and chickens for their own use. The sameness of their existence and the shared insecurity drew the people of these camps into tight community networks as uniform poverty circumscribed their lives.

Politics distinguished the "Little Balkans" of southeastern Kansas from other mining areas. Girard, the seat of Crawford County and a familiar name to students of American socialism, was the site of a socialist press which published the national socialist weekly the Appeal to Reason, along with The Coming Nation and The Progressive Woman. Eugene Debs lived in Girard for a number of years and Kate Richards O'Hare, Mother Jones and a number of other socialist luminaries frequently visited the area for camp meetings, union conventions, and Fourth of July celebrations. ${ }^{26}$ " Mother,' especially, was well known to the members and leaders of UMWA District 14. The Socialist party had an active following in the camps; indeed, many camps had several elected Socialist officials. Arma, for example, boasted all Socialist officials in 1911 while Dunkirk relied on an entirely Socialist school board. ${ }^{27}$ The Industrial Workers of the World added to the radical activity in southeastern Kansas although they organized primarily in the oil fields of Butler County and among migratory wheat harvest workers. ${ }^{28}$ By 1920, activities of the Kansas Communist party attracted the attention of the state Attorney General's office to Kansas's "red sector." 29

The area also produced its own "Jennie Higginses,"' socialist activists who, as Neil Basen reminds us, performed critical roles as "community educators and leaders" in the decentralized southwestern socialist movement. Laura A. Lasater of Pittsburg, for example, "a blue-collar widow" served as district clerk of Crawford County, Luella Roberts Krehbiel of Coffeyville, a state organizer, held "parlor propaganda meetings"' 30 and Mary Skubitz of Ringo led

\footnotetext{
${ }^{26}$ Ray Ginger, The Bending Cross: A Biography of Eugene V. Debs (New Brunswick: Rutgers Univ. Press, 1949), 249; Nick Savatore, Eugene V. Debs: Citizen and Socialist (Urbana: Univ. of Illinois Press, 1982), 213.

${ }^{27}$ Wood-Simons, "Mining Coal and Maiming Men." Until February 1912 the Girard Times carried a "Socialist Page" purchased by the local Socialist party. As socialists increased in size and vocality most newspapers in the county including the Times started campaigns denouncing the party as a threat to home and church. Girard Times, 31 Oct. 1912; The Cherokee Sentinel, 1 Nov. 1912; The Mulberry News, 1 Nov. 1912; Walnut Eagle, 1 Nov. 1912.

${ }^{28}$ Clayton R. Koppes, "The IWW and County Jail Reform in Ks., 1915-1920," Kansas Historical Quarterly, 41 (Fall 1975), 63-85. Interview with George Gust, Pittsburg, 30 Aug. 1981. Mr. Gust remembers an organizer from "The Imperial Workers of the World" who worked with him in the Southeastern Kansas coal mines and intended to set up the "Imperial Wizzard" in the area to dominate the country.

${ }^{29}$ Statements by John Eber, 3 July 1920, and by John Hughes, 5 Jan. 1920. Kansas State Historical Society, Topeka, Ks.

${ }^{30}$ Neil K. Basen, "The 'Jennie Higginses' of the 'New South in the West': A Regional Survey of Social Activists, Agitators, and Organizers, 1901-1917,' in Sally Miller, ed., Flawed Liberation: Socialism and Feminism (Westport, Conn.: Greenwood Press, 1981), 91-92. See also James Green, Grassroots Socialism: Radical Movements in the Southwest, 1895-1943 (Baton Rouge: Louisiana State Univ. Press, 1978).
} 
the women's march in 1921. Thus trade union and radical politics enriched community life, even for women as isolated as those in southeastern Kansas.

Citizens of Crawford County were clearly distressed by this "enemy within," a fear heightened by the area's involvement in the bitter 1919-20 coal strike, as well as by the postwar "Red scare." Before the 1919 strike ended, mine operators had used the National Guard and college boys from Lawrence and Topeka as strike breakers. The strike engendered such anti-union feelings throughout the state that in 1920 the Kansas legislature passed the Industrial Court Act which outlawed strikes and subjected all labor disputes to arbitration by an Industrial Court. By 1921, there was sufficient nativist and anti-Catholic sentiment in Crawford County to support the founding of a Ku Klux Klan chapter which numbered 4600 members by 1924. ${ }^{31}$ The "army of Amazons," then, exacerbated these tensions between the mining camps and the society around them and at the same time, expressed the family needs and ethnic unity of the community.

In contemporary descriptions of the march itself, the most striking element is always gender. The very phrase, for example, "army of Amazons," or "'maddened Amazons," was used repeatedly by such "establishment" newspapers as the New York Times, Topeka Journal, Kansas City Times, and the Pittsburg Daily Headlight to convey a disturbance in the natural order of things. The New York Times editorialized about the Amazon warriors from the "Red sector" of Kansas under the headline "Extending the Sphere of Women": "What they did was less a demonstration of courage than a willingness to capitalize and exploit the weakness that is ascribed to them." "32

Similarly, the Topeka Journal evoked a military tone as it described the first day of the march.

Headed by the girl's band of Arma, playing martial music, "General" Annie Stovich, the Joan of Arc [sic] of the "Amazon army" led her invading hosts, already weary and footsore, into the enemy country this afternoon. ${ }^{33}$

The article went on to describe the "pent-up fury of the women" and claimed that "Men viewed the situation with alarm, for it was believed that even bayonets will not deter the strong, highly temperamental foreign women." The Kansas City Times cautioned readers not to underestimate the chaos in the coal fields for "stopping a mob of more than two thousand maddened Amazons is the task confronting [the sheriff]." ${ }^{34}$ In a symbolic sense, then, the Amazons posed

\footnotetext{
${ }^{31}$ Lila Lee Jones, "The Ku Klux Klan in Eastern Kansas during the 1920's," Emporia Research Studies, Emporia State College, 23 (Winter 1975), 22.

${ }^{32}$ New York Times, 15 Dec. 1921, 16.

${ }^{33}$ Topeka Journal, 14 Dec. 1921, 1.

${ }^{34}$ Kansas City Times, 14 Dec. 1921, 2.
} 
a threat that went far beyond a few days of disorder in a remote area of Kansas. They represented a social order at risk, the family under siege.

While critics cast the march in a threatening light, the marchers themselves and their supporters were eager to promote the "womanly" meaning of their actions. The marchers' initial manifesto, for example, issued the day before the march (December 11) proudly proclaimed in the name of "the wives of the loyal union men of Kansas" that "it is our duty to stand shoulder to shoulder with our husbands in this struggle. "35 Several days later, the socialist Appeal to Reason assured readers of the feminine restraint shown by the marching women.

The whole episode of the marching women was remarkably peaceful . . . conducted with . . . admirable restraint. . . . The demonstration throughout was more moral than physical in its nature. The wives of the strikers wished to shame the men who had returned to work-to enforce on their consciousness the fact that they had deserted their comrades in a righteous struggle. ${ }^{36}$

Although the march was viewed as "peaceful" by the labor press, mainstream journalists sharply disagreed. The controversy over the women's behavior during the march seems to have centered, then, about the issue of whether the women were acting out of an appropriate family ethic or brazenly displaying unfeminine qualities. The New York Times seemed to believe that they were doing the latter, for when it described the women's arrival at the mine on December 13, it included the following charge:

The workers' dinner buckets were taken and a bombardment of bread, butter. bacon, jelly, eggs and other food was begun. The buckets, as fast as they were emptied were smashed by the rioters. Coffee compartments were opened and the working miners as well as the Sheriff were showered with the drink intended for their lunch. Only two or three of the men resisted the women. ${ }^{37}$

Similar stories of violence were reported after the march. Richard J. Hopkins, the Attorney General of Kansas complained of the difficulty of finding prosecution witnesses. One potential witness, who was driving to work in one of the mines, ". . . was stopped and badly beaten by several of the women and refused to file a complaint altho [sic] he knew and recognized more than one of his assailants." 38 The fear of community sanctions, it would seem, at least in this case, superceded legal or police pressure.

In another explicitly identified incident, Mrs. Nick Bossetti and Mrs. Walter

${ }^{35}$ Reprinted in full with signatures in Pittsburg Daily Headlight (hereafter PDH). 12 Dec. 1921, 1.

${ }^{36}$ Appeal to Reason, 14 Jan. 1922, 1.

${ }^{37}$ New York Times, 13 Dec. 1921. Mrs. Anna Okorn did remember a “Mrs. Nino" hitting a miner on the head with his dinner pail.

${ }^{38}$ Topeka Daily Capital, 20 Dec. 1921, 1. 
Carbaugh were arrested following the march and accused of assaulting Walter Madden at Central Mine \#49. They supposedly dragged him out of the mine office, beat him and tore his clothing. ${ }^{39}$ Finally, one paper told of a miner who was stripped and paraded through the town of Frontenac in a motorcar. "Women thrust pins into his flesh and shouted: 'Now, will you go back to work you dirty scab.", 40

The two ideological camps stood divided on other issues as well. In addition to highlighting the violence, opponents of the march questioned the leadership and initiation of the women's march. Officials tried to make a case that a few militants coerced many women into participating in the march and down-played the significant size and duration of the three-day disturbance. To this end, they found several women, including one schoolteacher from Ringo, who repudiated their participation in the march and identified the speakers at the December 11 organizational meeting as Mary Skubitz, a Socialist activist, a Mrs. Wilson and Dr. P. L. Howe. ${ }^{41}$

Another effort to discredit the march, at least as an autonomous activity of working-class women, was made by the New York Times which claimed "the Howat forces sent their women into the fight. . . "42 Journalist Henry J. Haskell also wrote in The Outlook that "radical Howat followers undertook a policy of terrorism. Women were incited to lead mobs and threaten miners who stood by the International." 43 Yet another reporter endorsed the opinion that the "women have been skillfully and effectively tutored in their meetings and in their marches." 44 In a similar vein, Van Bittner, provisional president of District 14 , censured cowardly men who sent their mothers, wives and sisters out to riot.

The need to identify the march as carefully planned by male leaders reflected mainstream society's ever-present fear of an alien conspiracy, so prevalent in postwar America. Playing perhaps on that fear of the "enemy within," one miner, when asked how the women assembled so quickly, sarcastically replied: "We have a wireless that calls them together just as the superintendents of the mine find out the secrets of our union meetings. It's our own grapevine." 45 In

${ }^{39} \mathrm{PDH}, 19$ Dec. $1921,1$.

${ }^{40}$ Kansas City Times, 17 Dec. 1921, 2.

${ }^{41}$ On 29 December 1921, for example, police arrested Mrs. John Morris of Camp 51, the wife of a miner and mother of seven children. Mrs. Morris, along with Mrs. Carrie Didlott of Ringo expressed their regret at having marched, as did Miss Tillie Roitz, a schoolteacher at Ringo. Roitz protested the revocation of her teacher's certificate and pointed out that wives of members of the school board had participated in the march. Her brother, she said, was in World War I and she herself taught Americanism to her students. PDH, 17 Jan. 1922.

${ }^{42}$ New York Times, 15 Dec. 1921, 16.

${ }^{43}$ Henry Haskell in The Outlook, 129 (28 Dec. 1921), 680-81.

${ }^{44}$ Kansas City Times, 15 Dec. 1921, 10.

${ }^{45}$ Ibid. 
contrast to this sense of subversion, the Appeal to Reason stated that "the idea of marching was entirely spontaneous with the women. None of the Howat leaders advised this tactic, and Howat from his jail cell, expressed his regret that the violence had occurred." 46 Another labor paper, the Workers' Chronicle noted that men were barred from the organizational meeting Sunday night ${ }^{47}$ and, finally, Fannie Wimler, an active participant in the march responded to Bittner's charges in a letter to the Pittsburg Daily Headlight:

\begin{abstract}
Husbands, sons and brothers aren't cowards and haven't anything to do with our affairs. We are doing this on our own accord, and what we mean is business . . . If you don't think us responsible, we'll just have to put the responsibility on you, for you are the one who is driving us to this. We don't want any bloodshed here in Kansas like there was in the Ludlow Strike, and in Alabama and Mingo County, West Virginia. What we want is our industrial freedom and liberty and we want our men to be good, true, loyal union men and 100 percent American citizens, not like you and your dirty bunch of strike breakers. In the World War we bought liberty bonds. ${ }^{48}$
\end{abstract}

In addition to its proclamation of autonomy, Wimler's letter struck the patriotic tone of the marcher's original statement. It reflected as well a solidarity which linked their action to labor struggles elsewhere and a conception that their cause was truly American.

Despite these seemingly polarized descriptions of the same events, both defenders and detractors agreed that women's natural role was domestic and privatized. However, although gender ideology united these two camps, they divided once again over their interpretation of the sort of behavior the ideology should foster. For the opponents of the march, the women's actions violated appropriate concepts of femininity; for supporters, those same actions upheld the basic tenets of womanhood.

The statement issued by the women before the march expressed their beliefs about women's social role. The proclamation was given by "the wives of the loyal union men of Kansas" and condemned both the "Alien Industrial Slavery Law" and the international union. Proudly they proclaimed, "it is our duty to stand shoulder to shoulder with our husbands in this struggle." Finally, they defined their struggle as "the fight for our democracy that we was [sic] to receive after the World War." 49 In expressing their solidarity with male members of the mining community, the marchers' logic rhetorically linked the miners' struggle to American democratic ideals. They identified with ideals of

46John Gunn in the Appeal to Reason, 24 Dec. 1921, 1.

${ }^{47}$ Worker's Chronicle, 16 Dec. 1921, 1.

${ }^{48}$ Fannie Wimler in $P D H, 15$ Dec. $1921,4$.

${ }^{49}$ See note 35 above. 
justice and democracy which they felt should have been defended by the international union and in a larger sense, by the American government. Undoubtedly, the women considered their cause one of conserving values rather than of revolt, for the marchers felt they were behaving in an appropriately womanly fashion because they were defending their rights and the jobs of their husbands. While their view of the family was holistic, detractors found their behavior inappropriate and not fitting for women.

Their persistent use of the flag-they marched behind the flag, stretched it across the entrance to mines and forced strikebreakers to kneel and kiss the flag-clearly reflects the marchers' acute sensitivity to the labels "foreign" or "subversive." The marchers, it would seem, desperately sought to identify themselves as American, particularly in response to such statements as Governor Allen's proclamation that "the Kansas government does not intend to surrender to foreigners and their female relatives." 50

The flag conveyed a different meaning to critics of the march, however. One Kansas City paper devoted a lengthy article to the "brazen boldness of a mob of alien[s]" who "compelled miners who are American citizens to kiss the American flag." The xenophobic tone of the article-" "They were foreign faces, most of them, and the words that fell from the lips of the men and women were foreign. It was a jargon, and at the head of the fury were two American flags"-drew a sharp contrast between the "loyal citizens and lovers of Americanism" and the "followers of the deposed mine czar Alexander Howat." Religious metaphors evoked a sense of evil ritual akin to a witches' sabbath: "'You kiss the flag, damn you, and say you will not work' . . . amid blasphemy and profane cries the travesty was performed." 51 The flag, in other words, was sacred, the women's actions profane.

The paranoia of local and state officials about subversive female aliens underscored the rift that loomed between Kansans and the mining camps. In two telling examples of that distance, A. J. Curran, the judge of the district court of Pittsburg, wrote to Mrs. John Tracy, chairman of the Americanization committee of the Pittsburg Women's Auxiliary, about the law whereby naturalization of a male alien conferred citizenship upon his wife (especially threatening in light of the political rights and privileges conferred on women by the recently passed Nineteenth Amendment). As Curran stated: "It is a known fact that there are anarchists, communists, and bolsheviks among the alien women in this community. As you know it was the lawlessness of the women in this community a few months ago which made necessary the stationing of the state militia in our country for two months to preserve law and order." 52 In

${ }^{50}$ New York Times, 16 Dec. 1921, 1.

${ }^{51}$ Kansas City Times, 17 Dec. 1921, 1-2.

${ }^{52}$ Letter A. J. Curran to Mrs. John Tracy, dated 10 May 1922. Pittsburg State University Library, Pittsburg, Ks. 
another pronouncement, Al F. Williams, the U.S. District Attorney, threatened to deport the "worst radicals" for he claimed that "when a situation like the present arises they all flock together like so many sheep." "53 Faced with such sentiment, many marchers fled the area; authorities searched in vain for some women when warrants were issued for their arrest.

For Curran, Williams and others, the marching women threatened a political order that included disenfranchised immigrants and an economic order based upon docile workers. Conversely, the marchers staked claim to citizenship and economic equity. Most importantly, each side struggled with a definition of femininity which was used both to condone and to condemn the march. The marchers presented themselves as maternal, patriotic and motivated by family concerns. Their critics labeled them alien, violent and incapable of autonomous action. Both, however, as demonstrated by their words and actions, shared a conception of women as inherently domestic.

On one level, of course, the women's motives were quintessentially domestic, like those of thousands of other women who have engaged in militant activity for traditional goals. History's pages are animated by women who have marched in bread riots, Kosher meat boycotts, as well as in mining strikes, to defend threatened family economies. ${ }^{54}$ Rather than isolating women in households, this dependency drew them into the political life of the community, as illustrated by their strength and initiative in the march. As the historian Meredith Tax reminds us, "These women had their own reasons for wanting to fight. In the company towns and migrant labor camps of the West, people were oppressed as members of family units rather than as individuals." 55 And as Mrs. Anna Okorn, a miner's widow, reflected some sixty years after the strike, "People were starving, Mr. Howat was in jail and it wasn't fair." 56

There are, though, even wider implications in this march for the study of American culture and women's history. As social scientists suggest, in episodes of collective behavior, ideologies and myths which lie beneath the surface of a society emerge. Thus the march discloses information about the roles, values

53PDH, 29 Dec. $1921,1$.

${ }^{54}$ Natalie Z. Davis, "Women in the Crafts in Sixteenth-Century Lyon," Feminist Studies, 8 (Spring 1982), 47-80. Paula E. Hyman, "Immigrant Women and Consumer Protest: The New York City Kosher Meat Boycott of 1902," American Jewish History, 70 (Sept. 1980), 91-105. Temma Kaplan, "Class Consciousness and Community in 19th Century Andalusia," in Maurize Zeitlin, ed., Political Power and Social Theory, vol. 2 (Greenwich, Conn.: JAI Press, 1981). Specific instances of demonstrations by women in mining communities can be found in Harvey, The BestDressed Miners, 283ff. Charles J. Bayard, "The 1927-1928 Colorado Coal Strike," Pacific Historical Review, 32 (1963), 235-50; Industrial Worker, 5 Aug. 1916, 1; Victor Greene, The Slavic Community on Strike (Notre Dame, Ind.: Notre Dame Press, 1968), 143-44; Corbin, "Life, Work and Rebellion," 92-93.

${ }^{55}$ Tax, The Rising of the Women: Feminist Solidarity and Class Conflict, 1880-1917 (New York: Monthly Review Press, 1980), 127.

56Interview with Mrs. Anna Okorn, 29 Aug. 1981, Pittsburg, Ks. 
and political consciousness of women in this working-class community. The march itself tells in its own "language"' how work, class and politics shaped the subculture of a community suffering hegemonic pressure from the distinct and dominant culture around them. The way in which contemporary observers structured the narrative of the event, evoking images of "Amazons" and foreign hordes, shows that the women's march represented a clear and distinct challenge to a social order based upon separate social roles of men and women as well as upon docile and subservient foreign workers. The marchers symbolically used the traditional American flag to invoke a heritage of American democracy and their claim to the rights of citizens. As women, they went to their kitchens for their weapon, red pepper. By emptying dinner buckets, they further conveyed the message that the food which nurturant women had always given freely they could violently take away.

Several issues about such demonstrations remain problematic, however. The first is the political consciousness of the marching women. Were they aware of the ways in which class determined their situation and of the political issues of the strike? Did they act on that awareness, designing the march as an effective instrument of protest? In the case of the Kansas march, it is clear that miners who returned to work posed a political threat to mining camp communities. They shattered the cohesiveness of the working-class communities and broke the balance of cooperation that sustained these communities in tension with the world around them. Given the radical climate around them, women who marched certainly could have perceived the political dimensions of their actions, or, like Mrs. Okorn, they could have been more simply motivated by the daily reality that "people were starving and it wasn't fair."

A wide array of scholars-anthropologists, sociologists, rhetoricians, historians-have been intrigued by dramatic social behavior. ${ }^{57}$ Influenced recently by linguistic theory they have turned their attention to the specific "language" used by participants in mass demonstrations. The French historian Emmanuel LeRoy Ladurie, for example, analyzed a sixteenth-century carnival as a "symbolic revelation of an [emerging] urban consciousness" in the "common people's state of mind." 58 In much the same way, I believe, the women's march reflects women's participation in the unique work culture of the mining community. Just as Ladurie's citizens justified themselves and their

\footnotetext{
${ }^{57}$ Some examples include: Emmanuel LeRoy Ladurie, Carnival in Romans (New York: George Braziller, Inc., 1979); George Rude, Ideology and Popular Protest (New York: Pantheon, 1980); Louise A. Tilly and Charles Tilly, eds., Class Conflict and Collective Action (Beverly Hills: Sage Publications, 1981); Victor Turner, Dramas, Fields and Metaphors (Ithaca: Cornell Univ. Press, 1974); Kenneth Burke, A Grammar of Motives (New York: Prentice-Hall, 1945); Joseph R. Gusfield, Symbolic Crusade: Status Politics and the American Temperance Movement (Urbana: Univ. of Illinois Press, 1963).

${ }^{58}$ Ladurie, Carnival in Romans.
} 
actions in religious terms, using a particular religious "code," so did the Kansas women legitimate their behavior with a symbolic lexicon drawn from democratic and domestic ideologies shared by proponents and opponents of the march alike. Each side believed in flag and family, but each defined those ideologies in dramatically different ways. The key issues which concerned both the marchers and their critics-the direction of the march, the definitions of femininity and of appropriate feminine behavior, the role of an American and its corresponding rights demonstrate important elements in these ideologies and the way in which a particular experience of work, family life and politics led to a uniquely working class interpretation of fundamental American values.*

*I am deeply grateful to Eugene DeGruson of Pittsburg State University who introduced me to the people and historical resources of southeastern Kansas. I also appreciate the critical readings given this article by Karlyn Kohrs Campbell, Andrew Debicki, Elizabeth Kuznesof, Scott McNall and members of the Mellon Faculty Development Seminar at the University of Kansas. Elizabeth Shiels provided essential assistance in the quantitative aspects of the paper and John Clark gave useful advice about the coal industry in the 1920s. 